\title{
Evaluation of Fruit Flesh Explants of Zaghloul and Samany Date Palm Cultivars for Micropropagation
}

\author{
I. S. Abd El-Magid" and M. H. Abed E-Zahaer ${ }^{* *}$ \\ ${ }^{*}$ Fruit Breeding Department, Horticulture Research Institute, \\ Agricultural Research Centre and ${ }^{* *}$ Pomology Department, \\ Faculty of Agriculture, Cairo University, Cairo, Egypt.
}

\begin{abstract}
7 HIS INVESTIGATION began as an attempt to micropropagate 1 the desirable cultivars of date palm (Zaghloul and Samany) beginning from segments of fruits flesh to obtain initial callus, compact callus and meristematic center cells. For this purpose, a study was conducted to define micropropagation protocol based on the cell totipotency to obtains formation of callus. Sodium hypochlorite was very effective for surface sterilization of explants. The best method of surface sterilization was achieved by using treatment containing $\mathrm{NaOCl} 70 \%$ that produced the lowest percentage of contamination $1.33 \%$ for Zaghloul and $1.58 \%$ for Samany explants by time expanding during sterilization period from 10 to 30 mint. It was observed that the highest percentage of callus was produced at Khalal stage than other stages of fruit development of Zaghloul and Samany cv., when culturing fruit flesh in MS medium containing $100 \mathrm{mg} / 1$ of 2,4-D or 30mg/l of Picloram (Pic). The effect of phy siological stage of fruit and growth regulators on callus browning was investigated. The results indicates that the treatment supplemented with Pic $(30 \mathrm{mg} / \mathrm{l})$ produced the highest amount of total soluble phenols in callus 3.73 $\mathrm{mg} / 100 \mathrm{~g}$ F.W for Zaghloul at Rutab stage and $3.42 \mathrm{mg} / 100 \mathrm{~g}$ F.W for Samany at kimri stage. On the other hand, there were significant differences between all stages on total soluble phenols of callus in Zaghloul. While there was no any significant difference among Khalal and Rutab stage on callus formation from Samany explants. The stages of initial callus formation and callus percentages of date palm (Phoenix dactylifera L.) were studied from the 2-10 months-old cultures in MS medium containing 2,4-D or Pic at different concentrations. The study revealed that the compact callus was formed from the friable callus and meristematic center cells. The number of these center cells were unequally distributed inside the compact callus.
\end{abstract}

Keywords: 2,4-D, Picloram , Anatomy, Callus, Date palm, Phenols, Tissue culture

Date palm (Phoenix dactylifera L.) is affected by a disease syndrome known as Bayoud, primarily caused by Fusarium oxysporum f.sp. albedinis, which has already destroyed 3 millions of trees (Djerbi, 1988) .

The efficiency of tissue culture for competitive cell line selection is hampered by the loss of cell totipotency in a relatively short time. The cell 
proliferation in prolonged time and the maintenance of cell totipotency is an essential step for cell manipulation.

Numerous papers have been published that described somatic embryogenesis regeneration in date palm using various explant sources (Ammar \& Benbadiss, 1977, Drira, 1985, Tisserat, 1979 and Scarnec, 1991).

The use of somatic cell genetic techniques such as protoplast regeneration, cell hybridization and cell selection exhibit resistance to applied stress has been widely recognized as a tool to improve species (Karp et al., 1990). To explore the ability to grow plant cells by isolation, an efficient regeneration system is necessary to genetically transform species. Although monocotyledonous species have been shown to be recalcitrant in in vitro culture, plants can be regenerated from embryogenic cell suspensions and protoplasts from number of species (Morrish et al., 1987).

The first histological study of embryogenic callus in date palm was mentioned by Tisserat \& DeMeason (1980). They reported that the embryogenic callus composed of compact aggregates were dispersed among friable tissue. Also, the meristematic clusters probably derived from single cells were embedded in the callus and divided to form loci that acquired polarity when transferred to low auxin medium. Concerning the fruit anatomy, Al-Awdat and El-Deajy (1992) mentioned that the date palm fruits are simple succulent berry. Endocarp is consisting of single layer of small cells which could be seen in an early stage of fruit development. Mesocarp which comprise most of the part of fruit, is consisted of enlarged parenchymatous cells. The mesocarp is divided into outer-mesocarp and inner-mesocarp, between them there are 3-10 layers of tannin ferous cells. The exocarp consists of epidermis covered with cuticle, 3-5 layers of parenchymatous cells and stone cells in radial orientation.

The objective of present investigation is to study the cell totipotency of fruit flesh explants of date palm cultivars Zaghloul and Samany in callus formation at different developmental stages influenced by age of fruit and other determining factors such as different forms and concentrations of auxins.

\section{Materials and Methods}

The explants were collected from two varieties of date palm (Phoenix dactylifera L.) namely Zaghloul and Samany grown in Horticulture Reserch Station at El Kanater El Khayreia, Kalubia Gvernorate, Egypt to study the potentiality of fruit flesh in callus formation at different developmental stages viz. Hababok, Kimri, Khalal and Rutab.

\section{Sterilization experiment}

The explants were washed several times with liquid soap and water then placed under running tap water for 1-2 hours. Fruit flesh explants were prepared

Egypt. J. Hort. Vol. 42, No. 1 (2015) 
3-5 $\mathrm{cm}$ in length and were transfered to the laminar flow cabinet for further sterilization process. Sterilization was done by dipping explants in $70 \%$ ethanol for 5 minutes then transferred to different concentrations $(15 \%, 30 \% \& 70 \%)$ of sodium hypochlorite (NaOCL) solution for 10, 20 and 30 minutes. The explants were rinsed three times with sterilized distilled water ten minute for each and the contamination percentage was recorded. All tissue culture experiments were carried out during 2011-2013 in the tissue culture Laboratory, Horticulture Research Institute, Giza, Egypt.

The fruit flesh explants were cultured in small jars contained basal nutrient medium Murashige and Skoog (MS, 1962) for different in vitro experiments. The MS medium was supplemented with plant growth regulators $2 \mathrm{ip}$ ( $3 \mathrm{mg} / \mathrm{L})$, 2,4-D (10, 50 and $100 \mathrm{mg} / \mathrm{L}$ and Pic (10, 20, $30 \mathrm{mg} / \mathrm{L})$. The $\mathrm{PH}$ was adjusted at $5.7 \pm 0.1$ by adding few drops of either $0.1 \mathrm{KOH}$ or $0.1 \mathrm{HCl}$ before sterilization. The cultured explants were incubated at $27 \pm 2{ }^{\circ} \mathrm{C}$. Each treatment contained six replications each replicate has three explants

\section{Callus formation}

The cultures were incubated in dark at 27 to $29^{\circ} \mathrm{C}$ until callus was formed. After 18 to 24 weeks of culture, the fruit explants producing friable and compact callus were subcultured at 4 -weeks intervals on the same medium. The data was collected from $24^{\text {th }}$ to $36^{\text {th }}$ week for callus induction percentage at different fruit growth stages.

\section{Chemical analysis}

Plant samples were obtained for chemical analys is at different stages (Hababok, Kimri, Khalal and Rutab) of Zaghloul and Samany date palm cultivars.

\section{Determination of total soluble phenols}

The colorimetric method of folin-denis as described by Dani and George (1972) was employed for determination of total soluble phenols of fruit flesh tis sue samples $(0.1 \mathrm{~g})$ extracted by boiling in $80 \%$ aqueous ethanol and stored in cold conditions for $24 \mathrm{~h}$. The extracts were filtered and final solution was made to $50 \mathrm{ml}$ in measuring flask with ethanol $80 \%$. For estimation of total soluble phenols, $0.5 \mathrm{ml}$ of folin-Denis reagent was added to $1 \mathrm{ml}$ of ethanolic tissue extract and the tube was thoroughly shaken for $3 \mathrm{~min}$. Then, $1 \mathrm{ml}$ saturated $\mathrm{Na}_{2} \mathrm{CO}_{3}(25 \% \mathrm{w} / \mathrm{v})$ and $17.5 \mathrm{ml}$ distilled water was added. The mixtures were kept at $30-40^{\circ} \mathrm{C}$ for one hour. The rate of total soluble phenol absorbance was determined at $730 \mathrm{~nm}$ by using Spectrophotometer. The concentrations of total phenols in different samples were calculated as $\mathrm{mg} / 100 \mathrm{~g} \mathrm{FW}$.

\section{Anatomical study}

The samples of mature fruits were dissected and fixed in 70\% FAA solution, then dehydrated with ethyl alcohol series and infiltrate to study fruit anatomy. The samples were subsequently embedded in paraffin wax (M.P. $58^{\circ} \mathrm{C}$ ). According to Willey (1971) by using a rotary microtome, the sections $(20 \mu)$ 
were obtained and stained with Safranin and Fast-Green before being mounted in Canada balsam. Finally, the sections were examined microscopically and the different tissues were measured by eyepiece micrometer.

\section{Statistical analysis}

In all experiments the complete randomized design was used. Each treatment was replicated three times and every replicate was represented by six vessels (jars) each vessels had three explants. The data obtained from experiments devoted for studying effect of sterilization, callus production and callus content of phenol subjected to statistical analysis of variance. The separation of means among treatments was determined using LSD test at 5\%, according to Steel and Torrie (1980).

\section{Results and Discussion}

\section{Sterilization experiment}

This experiment was carried out in order to evaluate the effect of different $\mathrm{NaOCl}$ concentrations and times to obtain contamination free cultures of fruit flesh explants of Zaghloul and Samany date palm cultivars.

The data presented in Table 1 shows that the rate of contamination decreased in both cultivars (Zaghloul and Samany) by increasing sterilization time. The lowest contamination percentage was observed $2.39 \%$ in Zaghloul and $2.22 \%$ in Samany cultivars at 30 min sterilization time.

The effect of $\mathrm{NaOCl}$ concentrations to make explants contamination free showed significant differences among all of them, which resulted in decreasing contamination percentage in explants from $3.83 \%$ to $2.06 \%$ for Zaghloul and from $3.78 \%$ to $2.56 \%$ for Samany .

Whereas the interaction effects between $\mathrm{NaOCl}$ concentration and the serilization time, clearly showed that the treatment containing $70 \% \mathrm{NaOCl}$ produced the lowest contamination percentage for Zaghloul $(1.33 \%)$ and for Samany $(1.50 \%)$ by time expanding during sterliliation period from 10 to $30 \mathrm{~min}$.

It could be concluded from the results mentioned above that the best survival rate and less contamination percentage was achieved by using $70 \% \mathrm{NaOCl}$ (commercial bleach) with the sterilization period of $30 \mathrm{~min}$. These results are similar to those of Shatanawi et al. (1997) who used the $\mathrm{NaOCl}$ at concentration (1.32 and $2.65 \%)$ and mercuric chloride $(0.1 \%)$ as initial sterilizer for explant sterilization of Phoenix dactylifera L. obtained from axillary buds. They reported that the mercuric chloride gave the lowest contaminated buds and the highest survival $(91 \%)$ followed by $\mathrm{NaOCl}$ at $2.65 \%$. Awad (1999) reported that the highest survival percentage $(90 \%)$ achieved when shoot tip and leaf primordia explants of date palm Sewy cultivar were disinfected with $2.6 \% \mathrm{NaOCl}$ for 25 $\min$ followed by $1.3 \% \mathrm{NaOCl}$ for $15 \mathrm{~min}$. While, the survival percentage

Egypt. J. Hort. Vol. 42, No. 1 (2015) 
decreased to $75 \%$ when disinfected with $2.6 \% \mathrm{NaOCl}$ alone for $25 \mathrm{~min}$. AboHatem (2002) found that the best treatment for sterilization, which reduce contamination percentage explants to $12.5 \%$, was achieved by exposing shoot tip explants to double sterilization by $\mathrm{NaOCl}$ firstly at $60 \%$ for $20 \mathrm{~min}$ and secondly at $40 \%$ for $15 \mathrm{~min}$, after immersion in $70 \%$ ethanol for 5 seconds and $0.1 \%$ mercuric chloride $\left(\mathrm{HgCl}_{2}\right)$ for $5 \mathrm{~min}$.. Is lam (2007) reported that the sterilization period significantly increased the number of survived explant shoot tips and consequently the rate of contamination decreased for Zaghloul and Samany cultivars. It revealed the significant increase in explants survival rate at sterilization periods of 20 and $25 \mathrm{~min}$ as compared to 5 and $10 \mathrm{~min}$ by using $25 \%$ $\mathrm{NaOCl}$ concentration. However, there was no significant difference between 25 and $30 \mathrm{~min}$ sterilization period.

TABLE 1. Effect of different concentrations of NaOCL solution, sterilization time and their interaction on contamination percentage of fruit flesh explants of Zaghloul and Samany date pam cultivars.

\begin{tabular}{|c|c|c|c|c|c|c|c|c|}
\hline \multirow{2}{*}{$\begin{array}{l}\text { Time } \\
\text { Treat }\end{array}$} & \multicolumn{3}{|c|}{ Zaghloul } & \multirow{2}{*}{ Avg. } & \multicolumn{3}{|c|}{ Samany } & \multirow{2}{*}{ Avg. } \\
\hline & 10 & 20 & 30 & & 10 & 20 & 30 & \\
\hline $15 \%$ & $4.50 \mathrm{a}$ & $3.67 \mathrm{~b}$ & $3.33 \mathrm{~cd}$ & $3.83 \mathrm{a}$ & $4.33 \mathrm{a}$ & $4.00 \mathrm{ab}$ & $3.50 \mathrm{bc}$ & $3.78 \mathrm{a}$ \\
\hline $30 \%$ & $3.50 \mathrm{bc}$ & $2.83 \mathrm{de}$ & $2.50 \mathrm{e}$ & $2.94 \mathrm{~b}$ & $3.83 \mathrm{bc}$ & $3.00 \mathrm{~cd}$ & $2.67 \mathrm{de}$ & $3.00 \mathrm{~b}$ \\
\hline $70 \%$ & $2.67 \mathrm{de}$ & $2.17 \mathrm{e}$ & $1.33 \mathrm{f}$ & $2.06 \mathrm{c}$ & $3.17 \mathrm{~cd}$ & $2.00 \mathrm{ef}$ & $1.50 \mathrm{f}$ & $2.56 \mathrm{~b}$ \\
\hline Avg. & $3.56 \mathrm{a}$ & $2.89 \mathrm{~b}$ & $2.39 \mathrm{c}$ & & $3.94 \mathrm{a}$ & $3.17 \mathrm{~b}$ & $2.22 \mathrm{c}$ & \\
\hline \multicolumn{9}{|c|}{$\begin{array}{ll}\text { L.S.D at } 0.05 & \text { L.S.D at } 0.05\end{array}$} \\
\hline Treat. A & \multicolumn{3}{|c|}{0.4663} & reat. A & \multicolumn{3}{|c|}{0.4867} & \\
\hline Time. B & \multicolumn{3}{|c|}{0.4663} & Time. B & \multicolumn{3}{|c|}{0.4867} & \\
\hline \multicolumn{4}{|c|}{ Treat $\mathrm{x}$ time $\mathrm{AB} 0.8076$} & \multicolumn{5}{|c|}{ Treat. $\mathrm{x}$ time. $\mathrm{AB} 0.8431$} \\
\hline
\end{tabular}

*Mean in each column, row or interaction has the same letters are not significantly different at $5 \%$ level for each cultivar .

Effect of growth regulators and different fruit stages on callus formation percentage in Zaghloul and Samany date palm cultivars

The results presented in Table 2 show that callus formed in Zaghloul and Samany cultivar explants was affected significantly by different treatments of growth regulators during different fruit flesh developmental stages. The highest percentage of callus produced (4.42\% in Zaghloul and $4.50 \%$ in Samany) when fruit flesh explants were cultured on MS medium supplemented with 2,4-D $(100 \mathrm{mg} / \mathrm{l})$. There were significant differences among all $10 \mathrm{mg} / \mathrm{l}, 50 \mathrm{mg} / \mathrm{l}$ and $100 \mathrm{mg} / \mathrm{l}$ concentrations of 2,4-D for both cultivars .

The effect of fruit flesh developmental stages revealed that the highest percentage of callus was produced at Khalal stage as compared to other stages in both cultivars. Regarding the interaction between fruit flesh developmental stages and different concentration of $2,4-\mathrm{D}$, it was clearly noticed that the treatment containing $2,4-\mathrm{D}(100 \mathrm{mg} / \mathrm{l})$ produced the highest percentage of callus $(5.50 \%)$ for Zaghloul followed by $5.33 \%$ for Samany cultivar at Khalal stage.

The results presented in Table 3 show that callus formed in Zaghloul and Samany cultivar explants was affected significantly by different treatments of 
picloram during different fruit flesh developmental stages. The highest percentage of callus was produced (4.63\% in Zaghloul and 3.95\% in Samany) when fruit flesh explants were cultured on MS medium supplemented with Pic (30mg/l).

The effect of fruit flesh developmental stages revealed that the highest percentage of callus was produced at Khalal stage as compared to other stages in both cultivars.

Regarding the interaction between fruit flesh developmental stages and different concentrations of Pic, it was observed that the treatment containing Pic $(30 \mathrm{mg} / \mathrm{l})$ produced the highest percentage of callus $5.00 \%$ in Zaghloul and $4.83 \%$ in Samany cultivar at Khalal stage .

These results are in agreement with those of Beyl and Sharma (1983) showed that the Picloram was more effective than 2,4-D for callogenesis, embryo induction and final yield of embryos in Gasteria and Haworthia. Li-Chun and Dauh-Lian (1988) who found that the maximum callus formation from shoot tip of banana (Musa sapientum) was achieved with 2,4-D (optimum concentration 5 x $10^{-4} \mathrm{mM}$ ), which was only half of that obtained with Pic at $5 \times 10^{-3} \mathrm{mM}$. Omar and Novak (1990) noticed that another auxin with properties similar to 2,4-D is Picloram. the Picloram has been successfully applied for callogenesis in date palm.

In this concern, Le-Thi-Lan-Hong et al. (1999) indicated that 12 weeks-old cultures on MS basal medium supplemented with $100 \mu \mathrm{M}$ Pic and $9.5 \mu \mathrm{M}$ kinetin produced embryogenic callus with very compact, pale yellow and nodular structures on zygotic embryo and shoot tip explants of Phoenix canariensis. Masmoudi et al. (2003) found that the callus formation from juvenile leaves and inflorescences of Deglet Nour date palm cultivar required between 4 to 8 months after cultured on MS liquid medium supplemented with 2,4-D (100 mg/l) and activated charcoal $(300 \mathrm{mg} / \mathrm{l})$. In addition, the medium was positively affected the differentiation of somatic embryos. Kaur and Kothari (2004) reported that Pic $(10 \mathrm{mg} / \mathrm{l})$ in combination with kinetin $(5 \mathrm{mg} / \mathrm{l})$ was found most effective for callus formation on immature inflorescences of Kodo millet (Pasplum Scrobiculatum L. cv. GPUK-3) than 2,4-D. Moreover, in addition to pale yellowish callus, the compact embryogenic callus was developed from the cut ends of explant after 2 weeks of culture.

Is lam (2007) reported that the treatment containing 30mg/l of Pic and 3mg/l of $2 \mathrm{ip}$ produced the highest amount of callus (5.67\%) in Zaghloul followed by Samany $(5.33 \%)$ after 12 week of culture from shoot tip explants. However, there was no significant difference between the callus percentages obtained from Zaghloul and Samany shoot tip explants cultured on the same medium containing 30mg/l of 2,4-D and 3mg/l of 2ip.

Egypt. J. Hort. Vol. 42, No. 1 (2015) 
TABLE 2. Effect of different concentrations of 2,4-D,fruit growth stages and their interaction of explants on callus formation percentage of Zaghloul and Samany date palm cultivars.

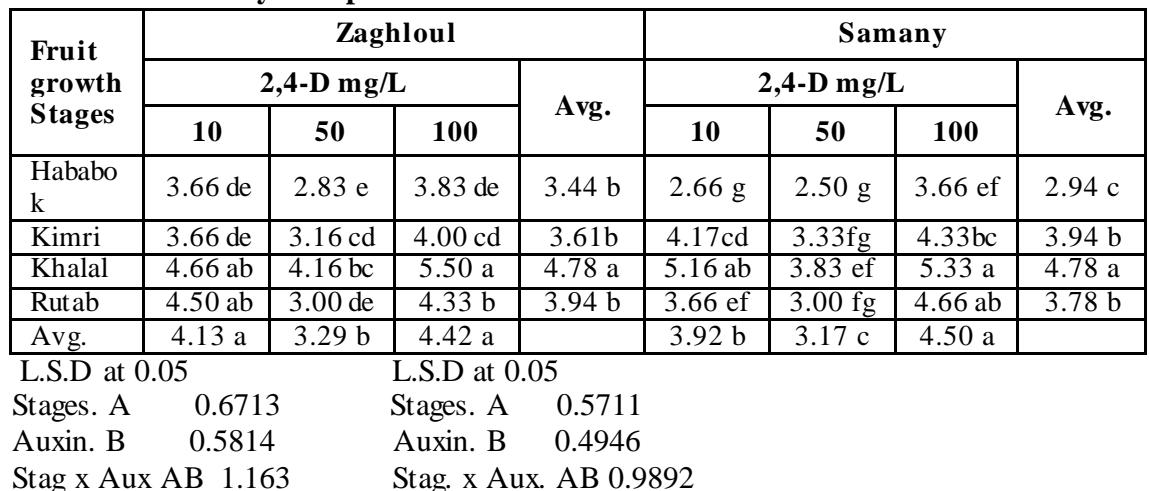

*Mean in each column, row or interaction has the same letters are not significantly different at $5 \%$ level for each cultivar .

TABLE 3. Effect of different concentrations of Pic ,fruit growth stages and there interaction of explants on callus formation percentage of Zaghloul and Samany date palm cultivars.

\begin{tabular}{|c|c|c|c|c|c|c|c|c|}
\hline \multirow{3}{*}{$\begin{array}{c}\text { Fruit } \\
\text { growth } \\
\text { Stages }\end{array}$} & \multicolumn{4}{|c|}{ Zaghloul } & \multicolumn{4}{|c|}{ Samany } \\
\hline & \multicolumn{3}{|c|}{ Pic mg/L } & \multirow{2}{*}{ Avg. } & \multicolumn{3}{|c|}{ Pic mg/L } & \multirow{2}{*}{ Avg. } \\
\hline & 10 & 20 & 30 & & 10 & 20 & 30 & \\
\hline Hababok & $2.83 \mathrm{f}$ & $3.33 \mathrm{ef}$ & $4.33 \mathrm{~cd}$ & $3.50 \mathrm{c}$ & $3.00 \mathrm{de}$ & $2.66 \mathrm{e}$ & $3.16 \mathrm{~cd}$ & $2.94 \mathrm{c}$ \\
\hline Kimri & $3.16 \mathrm{ef}$ & 3.50 ef & $4.66 \mathrm{ab}$ & $3.78 \mathrm{bc}$ & $3.66 \mathrm{~cd}$ & $3.00 \mathrm{de}$ & $4.16 \mathrm{bc}$ & $3.61 \mathrm{~b}$ \\
\hline Khalal & $5.00 \mathrm{ab}$ & $4.66 \mathrm{ab}$ & $5.33 \mathrm{a}$ & $5.00 \mathrm{a}$ & $4.50 \mathrm{ab}$ & $3.83 \mathrm{bc}$ & $4.83 \mathrm{a}$ & $4.39 \mathrm{a}$ \\
\hline Rutab & $4.50 \mathrm{bc}$ & $4.33 \mathrm{~cd}$ & $4.16 \mathrm{de}$ & $4.33 \mathrm{~b}$ & $3.00 \mathrm{de}$ & $3.00 \mathrm{de}$ & $3.66 \mathrm{~cd}$ & $3.22 \mathrm{bc}$ \\
\hline Avg. & $3.88 \mathrm{~b}$ & $3.96 \mathrm{~b}$ & $4.63 \mathrm{a}$ & & $3.54 \mathrm{ab}$ & $3.12 \mathrm{~b}$ & $3.95 \mathrm{a}$ & \\
\hline
\end{tabular}

L.S.D at $0.05 \quad$ L.S.D at 0.05

$\begin{array}{llll}\text { Stages. A } & 0.6034 & \text { Stages. A } 0.6034\end{array}$

Auxin. B $\quad 0.5226$ Auxin. B 0.5226

Stag x Aux AB 1.045 Stag. x Aux. AB 1.045

*Mean in each column, row or interaction has the same letters are not significantly different at $5 \%$ level for each cultivar.

The data in Table 4 shows that the total soluble phenols in callus formed in Zaghloul and Samany date palm explants was affected significantly by different auxin treatments during different stages of explant used in this study.

The effect of fruit flesh developmental stage revealed that the amount of total phenols of callus was increased significantly by different fruit flesh stages were maximum amounts are found in Zaghloul (2.88 mg/100g F.W) and Samany cultivar (3.07 mg/100g F.W) at Rutab stage.

The data presented in Table 4 also show the effect of different concentrations of 2,4-D on total soluble phenols production from callus. It was noticed that the treatment containing $100 \mathrm{mg} / \mathrm{l}$ of $2,4-\mathrm{D}$ produced the highest amount of total 
soluble phenol in callus of Zaghloul (3.49 mg/100g F.W) and Samany (3.17 $\mathrm{mg} / 100 \mathrm{~g}$ F.W) as compared to other treatments used.

Regarding the interaction between fruit developmental stages and different auxin treatments, it was observed that the treatment supplemented with $100 \mathrm{mg} / \mathrm{l}$ of 2,4-D produced the highest amount of total soluble phenol in callus of Zaghloul (3.96 mg/100g F.W) at Kahlal stage and Samany (3.70 mg/100g F.W) at Rutab stage.

The data presented in Table 5 shows that the total soluble phenols in callus formed from Zaghloul and Samany date palm explants was affected significantly by different Pic-treatments during different stages of fruit flesh explants. The effect of different fruit developmental stages revealed that the amount of total phenols in callus was increased significantly by different fruit flesh stages in Zaghloul (3.16 mg/100g F.W) and Samany cultivar (2.93 mg/100g F.W) at Rutab stage. Moreover, there were significant differences between all the stages of total phenol of callus in Zaghloul, while there was no significant difference between Khalal and Rutab stage for callus formation in Samany explants.

The data presented in Table 5 shows the effect of different concentration of Pic on total soluble phenols production. It was observed that the treatment containing 30mg/l of Pic produced the highest amount of total soluble phenols of callus in Zaghloul (2.96 mg/100g F.W) and Samany (2.92 mg/100g F.W)as compared to other treatments used .

Regarding the interaction between developmental stages and different Pic treatments, it was observed that the treatment supplemented with Pic $(30 \mathrm{mg} / \mathrm{l})$ produced the highest amount of total soluble phenols of callus in Zaghloul (3.73 $\mathrm{mg} / 100 \mathrm{~g}$ F.W) at Rutab stage and in Samany $(3.42 \mathrm{mg} / 100 \mathrm{~g}$ F.W $)$ at Kimri stage.

TABLE 4. Effect of different concentrations of 2,4-D,fruit growth stages and there interaction of explants on callus content of phenols $(\mathrm{mg} / 100 \mathrm{~g}$ fresh weight) of date palm Zaghloul and Samany cv.

\begin{tabular}{|c|c|c|c|c|c|c|c|c|}
\hline \multirow{3}{*}{$\begin{array}{l}\text { Fruit } \\
\text { growth } \\
\text { Stages }\end{array}$} & \multicolumn{4}{|c|}{ Zaghloul } & \multicolumn{4}{|c|}{ Samany } \\
\hline & \multicolumn{3}{|c|}{ 2,4-D mg/L } & \multirow{2}{*}{ Avg. } & \multicolumn{3}{|c|}{ 2,4-D mg/L } & \multirow{2}{*}{ Avg. } \\
\hline & 10 & 50 & 100 & & 10 & 50 & 100 & \\
\hline $\begin{array}{l}\text { Hababo } \\
\mathrm{k}\end{array}$ & $2.36 \mathrm{e}$ & $2.17 \mathrm{hi}$ & $2.96 \mathrm{~d}$ & $250 \mathrm{~d}$ & $1.84 \mathrm{i}$ & $2.60 \mathrm{ef}$ & $2.73 \mathrm{de}$ & $2.39 \mathrm{~d}$ \\
\hline Kimri & $2.29 \mathrm{gh}$ & $2.24 \mathrm{gh}$ & $3.32 \mathrm{c}$ & $2.61 \mathrm{c}$ & $2.01 \mathrm{hi}$ & $2.58 \mathrm{ef}$ & $3.12 \mathrm{bc}$ & $2.57 \mathrm{c}$ \\
\hline Khalal & $2.21 \mathrm{gh}$ & $2.03 \mathrm{i}$ & $3.96 \mathrm{a}$ & $2.74 \mathrm{~b}$ & $2.21 \mathrm{gh}$ & $2.86 \mathrm{~cd}$ & $3.12 \mathrm{bc}$ & $2.73 \mathrm{~b}$ \\
\hline Rutab & $2.57 \mathrm{e}$ & $2.35 \mathrm{eg}$ & $3.70 \mathrm{~b}$ & $2.88 \mathrm{a}$ & $3.13 \mathrm{~b}$ & $2.39 \mathrm{fg}$ & $3.70 \mathrm{a}$ & $3.07 \mathrm{a}$ \\
\hline Avg. & $2.36 \mathrm{~b}$ & $2.20 \mathrm{c}$ & $3.49 \mathrm{a}$ & & $2.30 \mathrm{c}$ & $2.61 \mathrm{~b}$ & $3.17 \mathrm{a}$ & \\
\hline \multicolumn{9}{|c|}{ L.S.D at 0.05} \\
\hline \multicolumn{9}{|c|}{ Stages. A $\quad 0.0818$} \\
\hline \multirow{2}{*}{\multicolumn{9}{|c|}{$\begin{array}{l}\text { Auxin. B } \\
\text { Stag } \times \mathrm{Au}\end{array}$}} \\
\hline & $\mathrm{AB} \quad 0.1$ & & Stag. $x$ & ux. AI & .2623 & & & \\
\hline
\end{tabular}

*Mean in each column, row or interaction has the same letters are not significantly different at $0.05 \%$ level for each cultivar

Egypt. J. Hort. Vol. 42, No. 1 (2015) 
TABLE 5. Effect of different concentrations of Pic ,fruit growth stages and there interaction of explants on callus content of phenols $(\mathrm{mg} / 100 \mathrm{~g}$ fresh weight) of date palm Zaghloul and Samany cv.

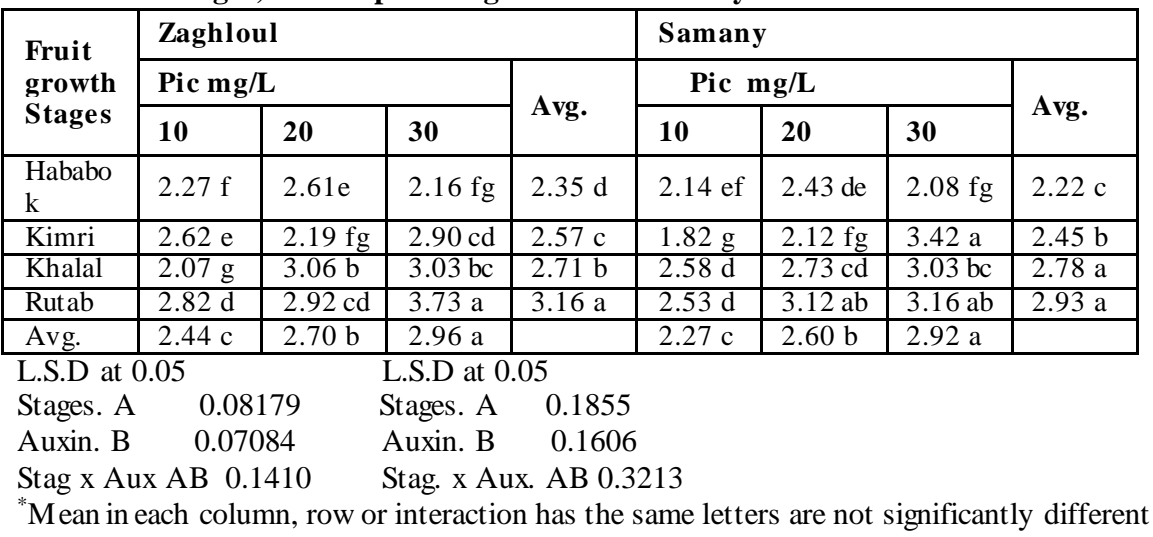
at $5 \%$ level for each cultivar.

These results are in agreement with Forrest (1969) showed that phenolics, especially the most common polyphenol, cause oxidative browning in explants, which lead to discoloration of the culture medium. Blake and Euwens (1982) found that the 2,4-D was the most effective for callus formation in date palm as compared to other auxins. However, Fitch et al. (1983) found that the Picloram produced more phenolics from cut surfaces and was slower for callogenesis than 2,4-D in sugarcane.

Sugimura and Salvana (1989) obtained similar results in coconut inflorescence explants of $1 \mathrm{~mm}$ in size, which showed $32 \%$ browning compared to $11 \%$ browning in $0.5 \mathrm{~mm}$ thick coconut inflorescence explants. Preece and Compton (1991) reported the synthesis of phenolics, tannins or oxidized polyphenols and flavonoid through shikimic acid pathways. Moreover, they stated that these substances are abundantly present in some plants and act as inhibitory agents. Furthermore, Bhat \& Chandel (1991) and Trautmann \& Visser (1991) reported that the oxidized phenolic compounds which frequently exuded into the medium by injured woody tissues cause lethal browning or blackening of explants. Jesty and Francis (1992) who reported that auxin at high doses $(5 \mathrm{mg} / \mathrm{l}$ or $3 \mathrm{mg} / \mathrm{l})$ was necessary for callus induction in palm, especially on medium supplemented with $1-3 \mathrm{~g} / 1 \mathrm{AC}$.

Abed El-Hamid (2002) revealed that there is negative correlation between dry weight and flavonoids or total phenols content of callus derived from shoot tip tissues of Sewy date palm cultivar. He reported that the highest value obtained was $0.412 \mathrm{mg} / 100 \mathrm{~g}$ total phenols and $0.1797 \mathrm{mg} / 100 \mathrm{~g}$ total Flavonoids under light condition. The lowest value obtained was $0.0921 \mathrm{mg} / 100 \mathrm{~g}$ total phenols and $0.421 \mathrm{mg} / 100 \mathrm{~g}$ total flavonoids under dark condition. Sukamto (2011) in his investigation for the factors that effect browning content of antipodal and micropylar of coconut endosperm tissues showed that the 
browning in antipodal tissues was more significant than micropylar tissues after 9, 26, and 31 weeks of culturing on MS medium supplemented with different concentrations of 2,4-D and Picloram. He reported that it could be due to antipodal tissues which were earlier formed (older) and thicker than micropylar tissues.

\section{Histological investigations}

One to three months-old cultures on MS medium supplemented with 2,4-D $(100 \mathrm{mg} / \mathrm{l})$ or Picloram $(30 \mathrm{mg} / \mathrm{l})$ showed that the initial callus started its growth to friable callus formation in the mesocarp. Whereas, after four to six months of culturing in the same medium the compact callus was formed from the friable callus and meristematic center cell emerge from the outer mesocarp in both the cultivars. The number of meristematic centers were increased in Zaghloul than Samany cultivar. However, most of the meristematic centers were formed inside the compact callus masses as shown in Fig 1-5. These results are coincided with Williams and Maheswarian (1980) who suggested that the indirect embryogenesis requires redetermination of differentiated cells \& callus proliferation. The development of embryogenically determined cells require growth regulators not only for re-entry into mitosis but also for determination of the embryogenic state. In addition, Abdulmunain (2003) found that the number of meristematic centers were increased in compact callus masses. Sakr et al. (2010) reported that the highest value for maximum thickness of stone cell layers was $132 \mu$ in Kuboshy, while the lowest value was $94 \mu$ in Hayany cultivar. the stone cells were found in continuous layers in all cultivars (Samany, Amhat, BintAisha, Hayany, Amry and Kuboshy) under investigation except in the Zaghloul cultivar, where they were found in groups (discontinuous), this character is unique to Zaghloul cultivar. The highest average thickness of outer-mesocarp was recorded 1.68, 1.14 and $1.05 \mathrm{~mm}$ in Kuboshy, Amhat and Zaghloul respectively. Whereas, the lowest values were noticed in Bint-Aisha $(0.37 \mathrm{~mm})$ and Hayany $(0.49 \mathrm{~mm})$ respectively. The average thickness of tannins region between outer and inner-mesocarp ranged 0.31 to $1.05 \mathrm{~mm}$ in Zaghloul and Samany cultivars respectively .

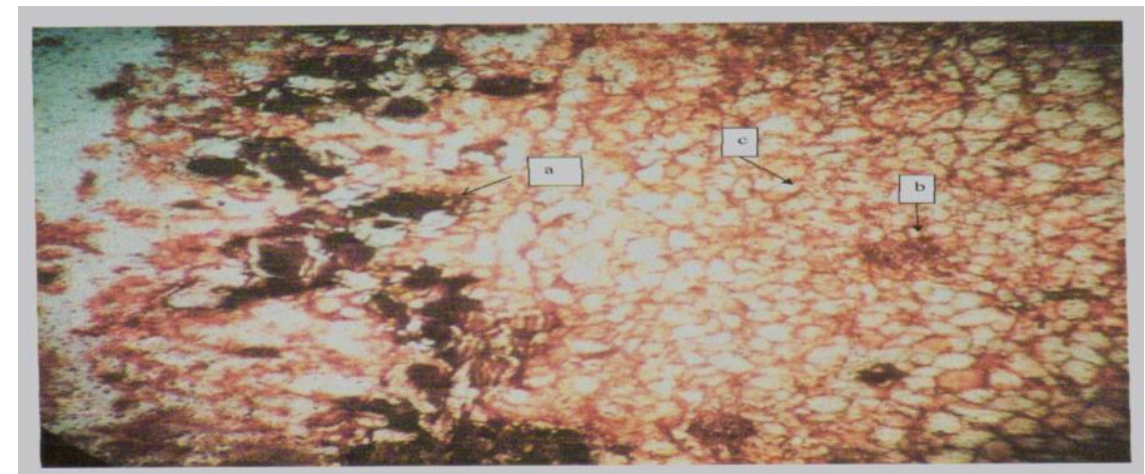

Fig. 1. Formation of callus from wounded surface of flesh fruit Zaghloui cv. Snowea tannins centers (a) and some meristematic centers (b) inside the compact callus (c) magnified $X=200$

Egypt. J. Hort. Vol. 42, No. 1 (2015) 


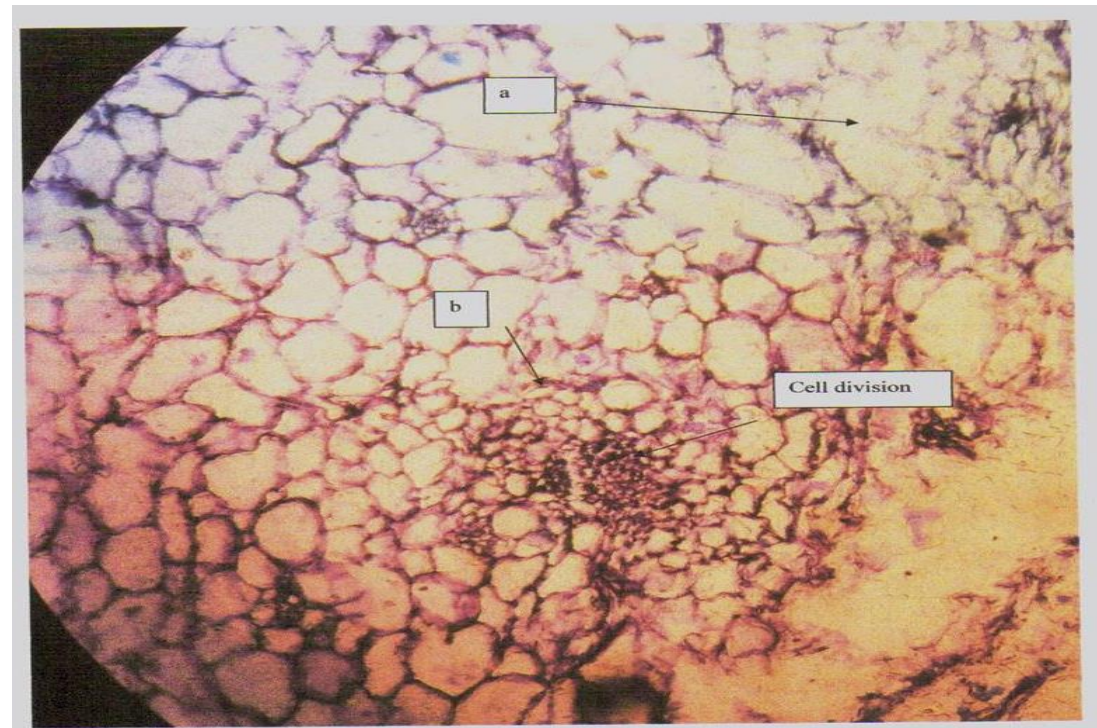

Fig. 2. A Cross section of callus growth showed of flesh fruit (mesocarpe) of Zaghloul c.v. magnified $x=400$

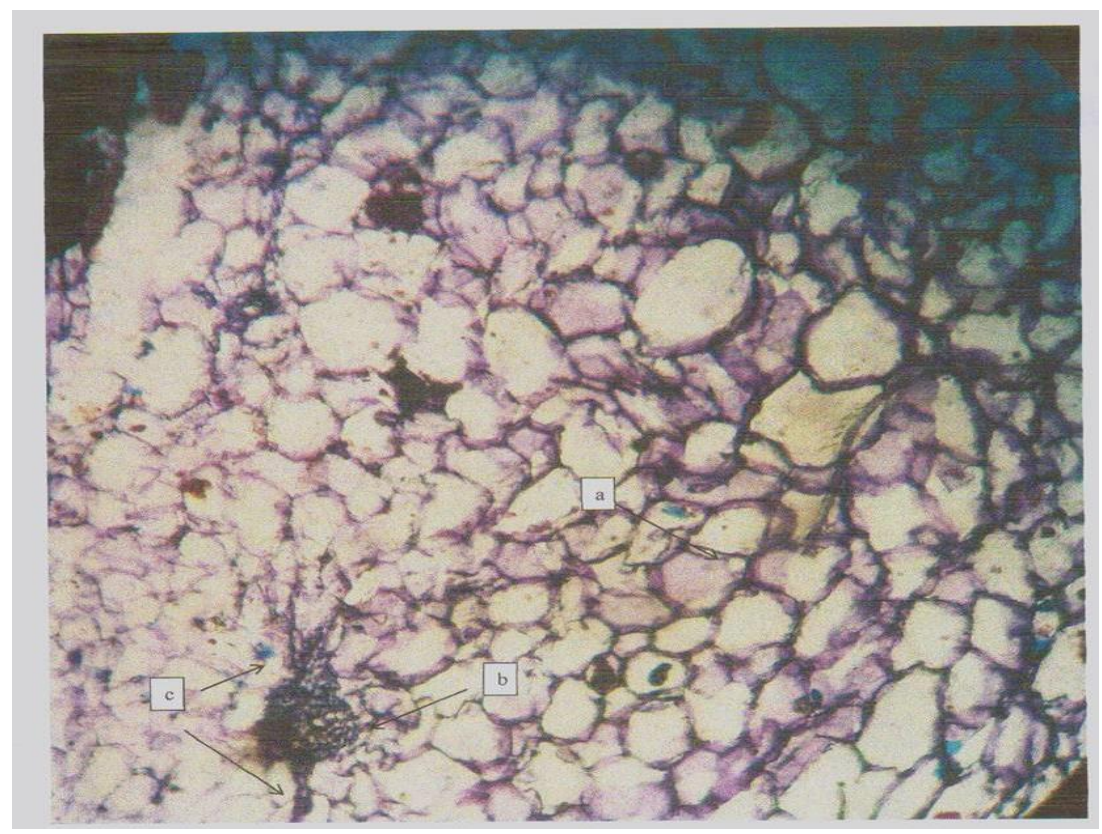

Fig. 3. The observers section at the compact callus (a) of flesh fruit (mesocarpe) of Zaghloul c.v. illustrated some meristematic centers (b) inside the compact callus, that developed into organs (c) magnified $x=400$ 


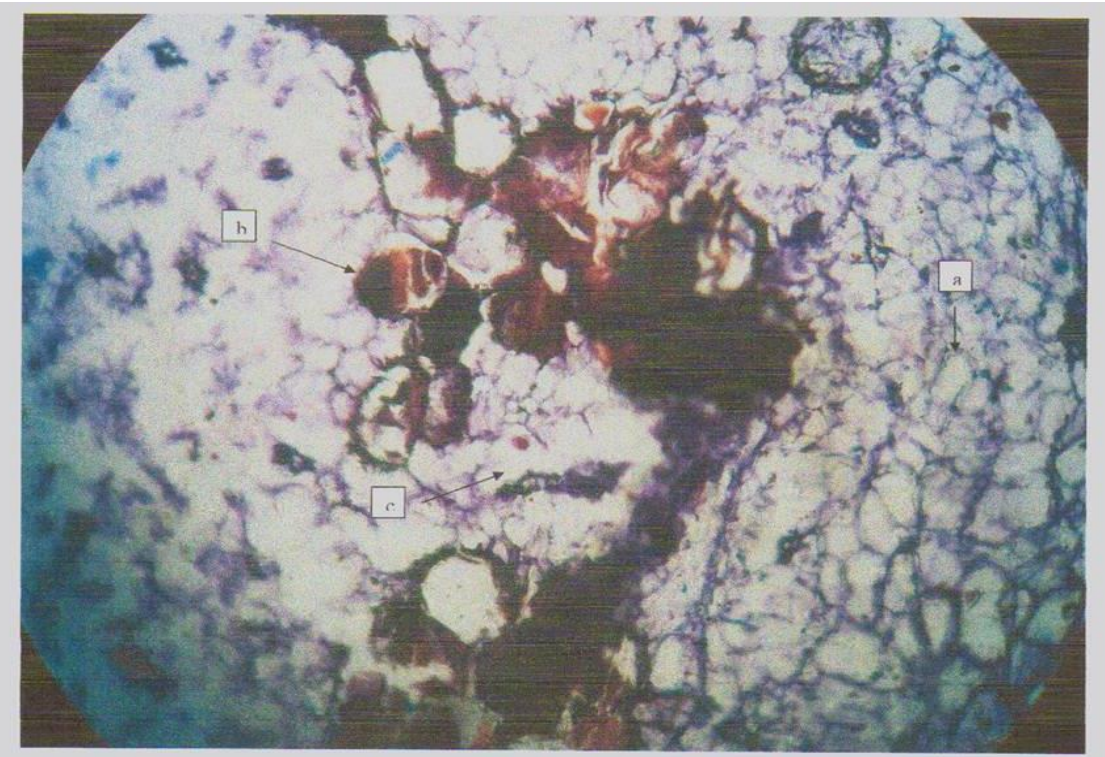

Fig. 4. A cross at the compact callus (a) of Samany flesh showed the stone cells (b) and the friable callus (c) that separated a part of the compact callus by a necrotic area magnified $x=400$

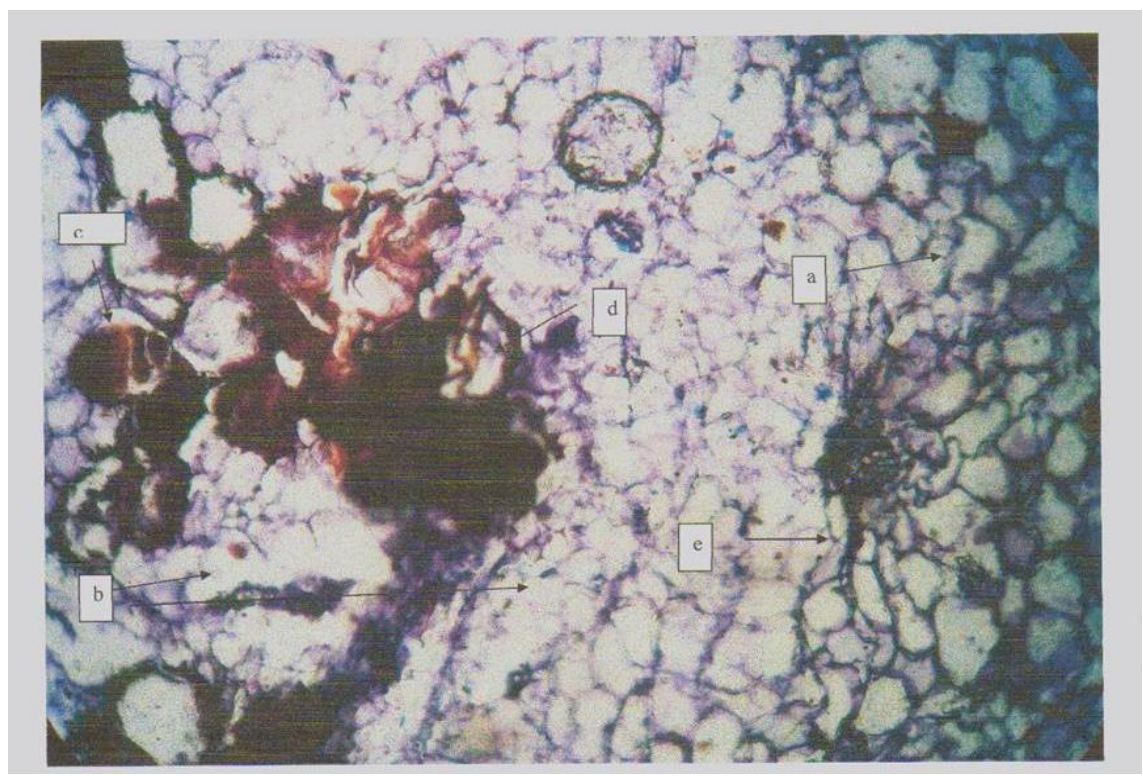

Fig. 5. A cross section at the callus of flesh fruit Samany cv showed the two types of callus (a: compact callus and b: friable callus ), stone cells (c) the separated zone (d) , some meristematic centers that de veloped into organs (e) magnified $\mathrm{x}=\mathbf{4 0 0}$

Egypt. J. Hort. Vol. 42, No. 1 (2015) 


\section{References}

Abo-Hatem, M.A.S. (2002) Studies on propagation of Zaghloul date palm cultivar by tissue culture. M.Sc. Thesis, Pomology Dep., Fac. Agric., Cairo Univ., Egy pt, pp. 4549.

Abdulmunam, H.A. (2003) Anatomical study of callus stages initiation and its development to embryoiods in date palm Phoenix dactylifera L. cultured in vitro. Damascus J. Agric. Univ. of Damascus, Syria, 19 (1), 127-140.

Abed El-Hamid, O.K.A. (2002) Studies biochemical Date Palm by usiing tissue culture techniques. Ph.D. Thesis, Biological Dep., Fac. Agric., Cairo Univ., Egy pt, pp. 60-65.

Ammar, S. and Benbadis A. (1977) Multiplication végéative du palmier dattier par la culture de tissus de jeunes plantes issus de semis. C.R. Acad. Sci. Paris, 284, 17891791Co.F

Al-Awdat, M. and El-Deajy, A.R. (1992) Plant morphology and anatomy. King Saudi University Press, Saudi Arabia, (In Arabic) pp. 39-42.

Awad, A.A. (1999) In propagation of date palm. Ph.D. Thesis, Dept. of Horticulture, Fac. of Agriculture, Ain Shams Univ., Shoubra El-Keima, Cairo, Egypt. pp. 50-52

Bhat, S.R. and Chandel, K.P.S. (1991) A novel technique to overcome browning in tissue culture. Plant Cell Rep., 10, 358-361.

Bhaskaran, S. and Smith, R. (1992) Somatic embryogenesis from shoot tip and immature inflorescence of Phoenix dactylifera L. cv. Brahee. Plant Cell Rep., 12, 2225 .

Blake, J. and Euwens, C.J. (1982) Culture of coconut palm tissues with a view to vegetative propagation. In: Tissue Culture of Economically Important Plants, Rao A.N. (Ed.), Proc Int Symp. Singapore, 145-148

Dani, 1.H.D. and George, C.M. (1972) Peach seed dormancy in relation to endogenous inhibitors and applied substance. J. Amer. Soc. Hort. Sci., 97, 651-654.

Djerbi, M. (1988) Les maladies du palmier dattier. FAO Projet Régional de lutte contre le Bay oud. 127

Drira, N., (1985) Multiplication végétative du palmier dattier par les néoformations induites en culture in vitro sur les organes végétatifs et floraux prélevés sur la phase adulte. Thèse de Doctorat Es Sciences, Fac. Sci. Tunis, 121(pp. 307-313)

Fitch, M.M., Moore, P.H.P. and Irvine, J.E. (1983) The use of picloram for maintenance of regenerative callus lines in long-term tissue culture of sugarcane. Plant Physiol. (Suppl) 72 (1), 46

Forrest, G.I. (1969) Studies on the polyphenol metabolism of tissue cultures derived from the tea plant (Camellia sinensis L.). Biochem. J., 113, 765-72. 
Islam, S. A. El-Mageid (2007) Physiological and histological studies on Samany and Zaghloul Date Palm cultivars produced via tissue culture techniques. Ph.D. Thesis, pomology Dep., Fac. Of Agric., Cairo Univ., Egy pt, pp. 55-58

Jesty, J.H.F. and Francis, D. (1992) Cellular responses of leaf explants of Cocs nucifera L. in vitro. Plant Cell, Tissue and Organ Culture, 28, 235-44.

Jones, L.H. (1974) Propagation of clonal oil palms by tissue culture. Oil Palm News, 17, $1-8$.

Karp, A., Jones, M.G.K. Jones, G.K. and Bright, S.W.J. (1990) Potato protoplasts and tissue culture in crop improvement. In Biotechnology of higher plants, Russell G. R. (Ed.), 1-32.

Kaur, Kothari (2004) Callus Friability and Somatic Embryogenesis in Hevea brasiliensis. Plant Cell Tissue Organ Cult., 33, 331-338.

Le-Thi-Lan-Hong, Baiocco, M. and Huong-L, T.L. (1999) Somatic embryogenesis in Canary Island date palm. Plant Cell Tiss. Org. Cult., 56 (1), 1-7.

Li-Chun, H. and Dauh-Lian, C. (1988) Pivotal roles of picloram and gelrite in banana callus culture . Enveronmental and Expermental Botany, 28 (5), 249- 258.

Masmoudi, Shakib, A., Modiri, and Nazeri, S. (2003) Study of Callus Induction from in vitro Culture of Different Parts of Date Palm. Seed Plant, 7 (1,2), 9-13.

Morrish F., Vasil V., Vasil, I.K. (1987) Developmental morphogenesis and genetic manipulation in tissue and cell cultures of the Graminae. Advances in Genetics, 24, 431-499

Omar, M.S. and Novak, F.J. (1990) Plant regeneration and ethyl-methane-sulphonate (EMS) uptake in somatic embryos of date palm ( L.). Plant Cell Tissue Organ Cult., 20, 185-90.

Preece, J.E. and Compton, M.E. (1991) Problems with explant exudation in micropropagation. In: Bajaj YPS (editor).Biotechnology in agriculture and Forestry, Vol 17: High-tech and Micropropagation I. Springer-Verlag, Berlin. 168-89

Sakr, M.M., AbuZeid, I.M., Hassan, A.E., Baz, A.G.I.O. and Hassan, W.M. (2010) Identification of some Date palm (Phoenix dactylifera) cultivars by fruit characters. Indian Journal of Science and Technology, 3 (3), 338-343.

Scarnec, A. (1991) La régénération in vitro du palmier dattier par organogenèse et embryogenèse somatique, Proc Int Symp. Singapore. pp.150-155

Steel, R.G. and Torrie, J.H. (1980) "Principles and Procedures of Statistics, a Biomerical Approach" . Mc Grow-Hill Book Company, New York, 469-517.

Sugimura, Y. and Salvana, M.J. (1989) Induction and growth of callus derived from rachilla explants of young inflorescences of coconut palm. Can J. Bot., 67(1), 272-74. 
Sukamto, L.A. (2011) Effect of physiological age and growth regulators on callus browning of coconut endosperm in vitro culture Biotropia, 18 (1), 31-41.

Tisserat, B. (1979) Propagation of date palm in vitro, J. Exe. Bot., 30 ,1275-1283.

Tisserat, B. and DeMeason, D.A. (1980) A histological study of the development of adventitive embryo in organ culture of Phoenix dactylifera L. Ann. Bot. 46,465-472 .

Trautmann, I.A. and Visser, J.H. (1991) The possible role of phenolic substances in the establishment of suspension cultures of guayule (Partbenium argentatum Gray). Bioresource Technology, 35 (2), 133-39.

Willey, R.L. (1971) Microtechnique: A Laboratory Guide. Memillan Publishing Co., Inc., N.Y., p. 99.

Williams, E.G. and Mahsawarian, G. (1980) Somatic embryogensis: Factors influencing coordinated behavior of cells as an embryogeneic group. Ann. Bot. 57, 443-462 (Review article).

(Received 15/1/2015;

accepted 17/5/2015) 


$$
\begin{aligned}
& \text { تقييم المنفصلات النباتية للحم الثمرة لصنفى نخيل البلح الزغلول والسمانى } \\
& \text { للإكثار الدقيق }
\end{aligned}
$$

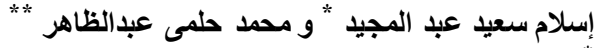

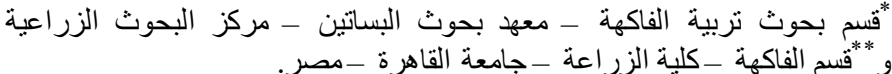

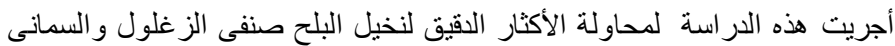

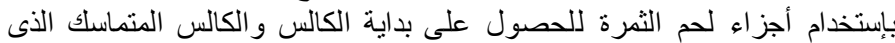

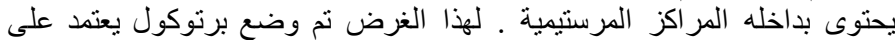
ققرة الخلية الجسدية على تكوين الكالس من الدنفصلات النباتئة للحم الثمرة .

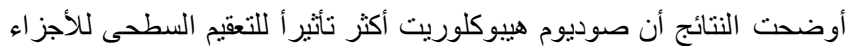

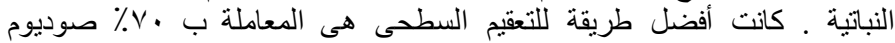

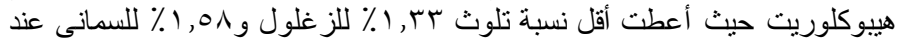

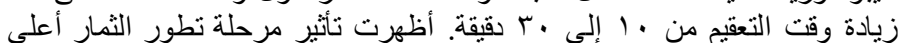

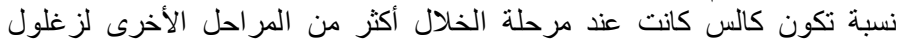

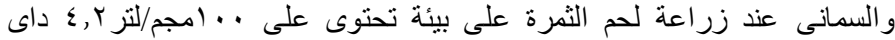

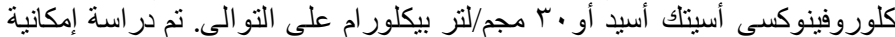

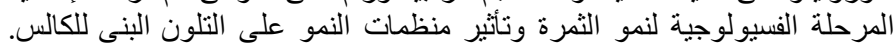

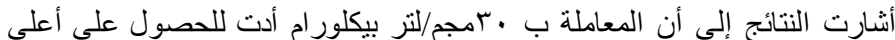

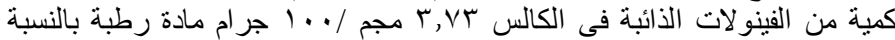

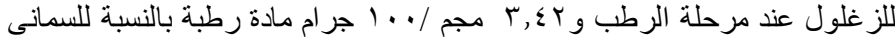

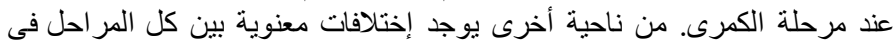

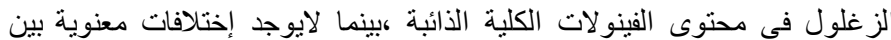

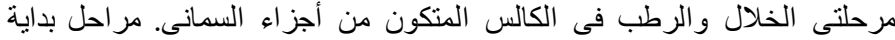

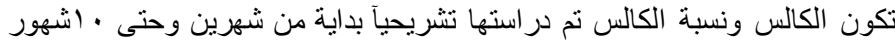

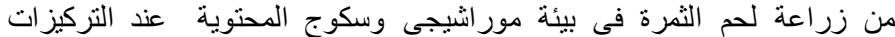

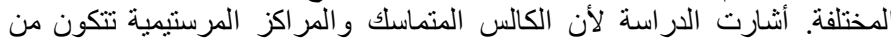
الكالس الرخو. عدد هذه المر اكز المرستيمية غير متساوى فى التوزيع داخل الكالس

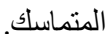

الكلمات المفتاحية : بيكلورام - داى كلوروفينوكسى أسبيتك أسيد - تثريحكالس -نخيل البلح-فينول- زر اعة الأنسجة. 